\title{
ANALYSIS OF THE SURVIVAL OF CIRRHOTIC PATIENTS ENLISTED FOR LIVER TRANSPLANTATION IN THE PRE- AND POST-MELD ERA IN SOUTHERN BRAZIL
}

\author{
Ângelo Zambam de MATTOS ${ }^{1,2}$, Angelo Alves de MATTOS ${ }^{1}$, \\ Fernanda Karlinski Fernandes SACCO' ${ }^{1}$ Lísia HOPPE ${ }^{3}$ and Denise Maria Sarti de OLIVEIRA ${ }^{4}$
}

\begin{abstract}
Context - Transplantation is the only cure for decompensated cirrhosis. Model for End-Stage Liver Disease (MELD) is used in liver allocation. Objectives - Comparing survival of enlisted populations in pre- and post-MELD eras and estimating their long-term survival. Methods - This is a retrospective study of cirrhotics enlisted for transplantation during pre- and post-MELD eras. Survival curves were generated using Kaplan-Meier's model. Cox's model was used to determine risk factors for mortality. Exponential, Weibull's, normal-log and Gompertz's models were used to estimate long-term survival. Results - The study included 162 patients enlisted in pre-MELD era and 184 in post-MELD period. Kaplan-Meier's survival curve of patients enlisted in post-MELD era was better than that of pre-MELD period $(P=0.009)$. This difference remained for long-term estimates, with a survival of $53.54 \%$ in 5 years and $44.64 \%$ in 10 years for patients enlisted in post-MELD era and of $43.17 \%$ and $41.75 \%$ for pre-MELD period. Era in which patients had been enlisted $(P=0.010)$ and MELD score at enlistment $(P<0.001)$ were independently associated to survival with hazard ratios of $0.664(95 \%$ CI-confidence interval $=0.487-0.906)$ and $1.069(95 \% \mathrm{CI}=1.043-1.095)$. Conclusion - MELDbased transplantation policy is superior to chronology-based one, promoting better survival for enlisted patients, even in long-term. HEADINGS - Liver cirrhosis. Liver transplantation. Survival analysis.
\end{abstract}

\section{NTRODUCTION}

Cirrhosis is the end-stage of chronic liver disease, and estimates are that it will continue to grow in importance among causes of deaths worldwide ${ }^{(25)}$. Cirrhosis can be classified in many ways ${ }^{(3,8,9,10,11,16)}$, the most used being Child-Turcotte-Pugh's classification ${ }^{(32)}$, which counts on empirically selected variables, has components which are subjective ${ }^{(12,19,22)}$ and suffers from a ceiling effect ${ }^{(21)}$, and Model for End-Stage Liver Disease (MELD) score ${ }^{(22,24)}$, which counts on objective parameters, can grade patients in a broader range of categories and has a well established capacity of predicting 3-month mortality in cirrhotics ${ }^{(4,8,19,21,22,35)}$.

Liver transplantation is the best treatment available for decompensated cirrhotic patients ${ }^{(8)}$, providing patients with a survival of $88.4 \%$ and $60 \%$ in 1 and 10 years in the United States of America (USA) ${ }^{(37)}$ and of $81.1 \%$ and $61 \%$ in 1 and 14.6 years in Southern Brazil ${ }^{(5)}$. Considering the scarcity of organ donors ${ }^{(1,5,17)}$, the fact that MELD classifies cirrhotics regarding disease severity and risk of death ${ }^{(12)}$ and the objective of opti- mizing organ allocation, the MELD system has been implemented for liver allocation since February 2002 in the USA and since June 2006 in Brazil ${ }^{(1,4,5,6,14,22,34)}$. Nevertheless, it is not completely clear if the allocation based on the MELD score is better than the one based on time spent in list (chronological system) ${ }^{(19)}$. Many studies have been published on the results of survival in the MELD era, but their results are contradictory. In the first year of the MELD-based allocation system in the USA, there seemed to be a reduction of mortality in the wait-list, without decreasing receptors' survival ${ }^{(14)}$. On the other hand, many authors have found that candidates with higher MELD scores had worse survival when transplanted ${ }^{(5,14,20,28,30,31,34,37,39)}$. Actually, it is not clear if transplanting more severely ill patients impacts negatively in post-transplant survival ${ }^{(7,13)}$.

There are at least three different rationales in which a transplantation policy could be based on: medical urgency, graft utility and survival benefit ${ }^{(35)}$. Since the latter seems the most sensible basis for an allocation policy ${ }^{(33,35)}$, considering the preoccupation that the MELD-based allocation could be only trans- 
ferring mortality from the wait-list to the post-transplant period ${ }^{(36)}$ and taking into account that organs are a limited public resource, the present study aimed at comparing the MELD-based transplantation policy to the previously used chronology-based one, by comparing the survival of the population in need of an organ, the enlisted population as a whole, regardless of the fact of being transplanted (an "intention-to-treat-like" approach). This study also intended to mathematically estimate long-term survival of enlisted population in both periods in order to verify if a possible advantage of one policy over the other would persist over time.

\section{METHODS}

This is a retrospective cohort study, in which cirrhotics enlisted to liver transplantation in the Transplant Central of the State of Rio Grande do Sul, Brazil, were evaluated.

All cirrhotics enlisted during de abovementioned periods were eligible for the study. Exclusion criteria were: indication of transplantation not being related to cirrhosis; having been transplanted previously; receiving an organ from a living donor; being under age 18 years.

Patients were consecutively enrolled and divided into two groups, one including the cases enlisted from January 2004 to December 2004, representing the pre-MELD group, in which time in list was the criterion for receiving an organ, and the other including those enlisted from June 2006 to December 2007 , representing the post-MELD group, when the severity of the cases, determined by the MELD score ${ }^{(22,24)}$, became the condition used to allocate the livers ${ }^{(30)}$.

Patients studied were listed by all 4 major liver transplantation teams of the State. All laboratory variables, as well as MELD scores, were obtained at the time of enlistment and, for patients who were transplanted, also before transplantation. MELD scores were calculated through the formula currently in use by the United Network for Organ Sharing ${ }^{(40)}$.

Survival of every patient was counted from the time of enlistment to the time of death or to December 31st of 2009, when patients were censored, irrespective of the fact of being transplanted or not, since this study aims at measuring the survival of the enlisted population as a whole. This was in order to make an "intention-to-treat-like" approach.

Data were collected from the Transplant Central and the Health Information Nucleus (Núcleo de Informacão em Saúde - NIT/DAT/CEVS/SES/RS) databases, which are government official datasets.

The present study was approved by the Ethics Committee of Irmandade Santa Casa de Misericórdia de Porto Alegre and by the Transplant Central of Rio Grande do Sul, respecting the Declaration of Helsinki of 1975 (Ethics Committee protocol number 3166/09).

Continuous variables were expressed as means and standard deviation (SD). Comparisons using variables without a normal distribution were submitted to Mann-Whitney's test. Comparisons using variables with a normal distribution were submitted to Student's $t$ test. Categorical variables were expressed as percentage and were submitted to Chi-square test. Statistical significance was considered for $P<0.05$.

Survival data were submitted to Kaplan-Meier's nonparametric model, and curves generated for the pre- and post-MELD groups were compared. Following this analysis, in order to estimate survival in longer periods of time, the curves were compared to the ones generated by the four most used parametric models in the context of survival analysis: exponential, Weibull's, normal-log and Gompertz's models. The best fitted curves in relation to those generated by Kaplan-Meier's model were chosen after comparison by graphic methods, by fit model equations and by the Akaike and Bayesian information criteria. The chosen curves were then used to project survival for the populations.

It was also performed the Cox's regression model, in order to estimate the hazard ratio for death between the pre- and post-MELD groups. We conducted both uni- and multivariate analysis, in which variables with a statistical significant difference in the univariate analysis or deemed to be of clinical significance were included in the model.

Statistical analyses were performed using Stata version 10.0 (StataCorp LP, College Station, Texas) and Predictive Analytics Software (PASW) Statistics version 17.0.

\section{RESULTS}

After analyzing for inclusion and exclusion factors, 346 patients were studied, 162 of them representing the pre-MELD group, and 184 representing the post-MELD group. In the pre-MELD era, 74 patients were transplanted $(45.68 \%)$, while, in the post-MELD period, 90 patients received an organ $(48.91 \%)$. Patients' characteristics at the time of enlistment are detailed in Table 1 and characteristics at the time of transplantation can be fully appreciated in Table 2.

When patients' characteristics were analyzed, considering the cause of liver disease, there was a difference between the pre- and post-MELD era groups both at time of enlistment and at time of transplantation. Even after patients with an alcoholic component causing cirrhosis $33.80 \%$ in the preMELD group and $21.40 \%$ in the post-MELD group at the time of enlistment and $31.90 \%$ and $16.40 \%$ respectively at the time of transplantation) were compared to the others, the difference remained ( $P=0.02$ for the time of enlistment and $P=0.047$ for the time of transplantation). Regarding the presence of HCC, patients in the post-MELD group carried more frequently this diagnosis both at the time of enlistment and at the time of transplantation $(P<0.001)$.

A subgroup analysis of the moment of enlistment, excluding patients with HCC, was performed. There were 160 enlisted patients without HCC in the pre-MELD era and 148 in the post-MELD period. From them, 72 and 64 were transplanted respectively. In this subgroup analysis, findings considering the differences between groups were similar to those presented for the entire studied population, except for MELD score at the time of enlistment, which was greater in the post-MELD group (17.12 vs $15.24, P=0.001)$.

Regarding survival, it was built a Kaplan-Meier's curve, representing the survival of all enlisted patients in 
TABLE 1. Characteristics of patients at enlistment in pre- and post-MELD eras

\begin{tabular}{|c|c|c|c|}
\hline Variables & Pre-MELD era & Post-MELD era & $P$-value \\
\hline Included patients & 162 & 184 & - \\
\hline Age (years) & $53.74(9.99)$ & $52.13(10.07)$ & 0.17 \\
\hline Male gender & $71.00 \%$ & $73.80 \%$ & 0.65 \\
\hline Hepatocellular carcinoma & $1.20 \%$ & $19.60 \%$ & $<0.001$ \\
\hline $\begin{array}{l}\text { Transplantation Team } \\
\text { Team } 1 \\
\text { Team } 2 \\
\text { Team } 3 \\
\text { Team } 4\end{array}$ & $\begin{array}{c}67.90 \% \\
4.30 \% \\
13.00 \% \\
14.80 \%\end{array}$ & $\begin{array}{c}61.40 \% \\
15.20 \% \\
8.70 \% \\
14.70 \%\end{array}$ & 0.007 \\
\hline Total Bilirubin - mg/dL (SD) & $3.04(4.19)$ & $4.09(7.70)$ & 0.008 \\
\hline Creatinine $-\mathrm{mg} / \mathrm{dL}(\mathrm{SD})$ & $1.23(1.18)$ & $1.11(0.62)$ & 0.27 \\
\hline Prothrombin Index - \% (SD) & $60.26(15.62)$ & $59.35(16.76)$ & 0.64 \\
\hline International Normalized Ratio (SD) & $1.55(0.54)$ & $1.52(0.39)$ & 0.57 \\
\hline Sodium - mEq/L (SD) & $138.06(5.65)$ & $136.05(5.32)$ & $<0.001$ \\
\hline Albumin $-g / d L(S D)$ & $3.08(0.64)$ & $3.07(0.66)$ & 0.90 \\
\hline MELD score (SD) & $15.24(5.99)$ & $16.21(5.79)$ & 0.05 \\
\hline
\end{tabular}

NOTE: Results expressed in means and standard deviations or in percentage.

TABLE 2. Characteristics of patients at transplantation in pre- and post-MELD eras

\begin{tabular}{|c|c|c|c|}
\hline Variables & Pre-MELD era & Post-MELD era & $P$-value \\
\hline Patients included & 74 & 90 & - \\
\hline Age (years) & $54.67(8.87)$ & $52.20(10.88)$ & 0.30 \\
\hline Male gender & $68.90 \%$ & $77.80 \%$ & 0.27 \\
\hline $\begin{array}{l}\text { Cause of cirrhosis } \\
\text { Hepatitis C } \\
\text { Hepatitis B } \\
\text { Alcoholism } \\
\text { Viral hepatitis + Alcoholism } \\
\text { Other }\end{array}$ & $\begin{array}{l}51.40 \% \\
5.60 \% \\
18.10 \% \\
13.90 \% \\
11.10 \%\end{array}$ & $\begin{array}{l}32.90 \% \\
11.00 \% \\
11.00 \% \\
5.50 \% \\
39.70 \%\end{array}$ & 0.001 \\
\hline Hepatocellular carcinoma & $2.70 \%$ & $28.90 \%$ & $<0.001$ \\
\hline $\begin{array}{l}\text { Transplantation Team } \\
\text { Team } 1 \\
\text { Team } 2 \\
\text { Team } 3 \\
\text { Team } 4\end{array}$ & $\begin{array}{c}73.00 \% \\
2.70 \% \\
8.10 \% \\
16.30 \%\end{array}$ & $\begin{array}{c}58.90 \% \\
6.70 \% \\
12.20 \% \\
22.30 \%\end{array}$ & 0.27 \\
\hline $\begin{array}{l}\text { Blood Type } \\
\text { A } \\
\text { B } \\
\text { AB } \\
\text { O }\end{array}$ & $\begin{array}{c}32.40 \% \\
16.20 \% \\
6.80 \% \\
44.60 \%\end{array}$ & $\begin{array}{c}39.10 \% \\
11.50 \% \\
4.60 \% \\
44.80 \%\end{array}$ & 0.69 \\
\hline Total Bilirubin - mg/dL (SD) & $2.18(1.67)$ & $5.69(9.25)$ & 0.002 \\
\hline Creatinine $-\mathrm{mg} / \mathrm{dL}(\mathrm{SD})$ & $1.36(1.45)$ & $1.41(1.24)$ & 0.63 \\
\hline Prothrombin Index - \% (SD) & $60.61(15.99)$ & $55.73(16.65)$ & 0.07 \\
\hline International Normalized Ratio (SD) & $1.53(0.46)$ & $1.63(0.50)$ & 0.17 \\
\hline Sodium - mEq/L (SD) & $149.60(103.86)$ & $136.12(5.93)$ & 0.24 \\
\hline Albumin $-\mathrm{g} / \mathrm{dL}(\mathrm{SD})$ & $3.36(0.66)$ & $2.92(0.68)$ & 0.001 \\
\hline MELD score (SD) & $14.74(4.97)$ & $18.20(7.22)$ & 0.002 \\
\hline
\end{tabular}

NOTE: Results expressed in means and standard deviations or in percentage 
the pre- and post-MELD groups, independently of having been transplanted or not, until December 31st 2009, when patients still alive would be censored (Figure 1). For the preMELD population, mean survival was of 3.16 years $(95 \%$ confidence interval - CI of 2.77-3.55). For the post-MELD patients, mean survival was of 2.52 years $(95 \% \mathrm{CI}=2.30$ 2.73). After submitting the abovementioned results to a Chi-Square Mantel-Cox log rank test, it was demonstrated that patients enlisted in the post-MELD era had a better survival curve than those enlisted in the pre-MELD period for a $P=0.009$. The post-MELD curve was more favorable than the pre-MELD one, even the pre-MELD group having a longer mean survival, because the post-MELD population was followed-up for a shorter time, impacting in its mean survival, but not in the shape of its survival curve.

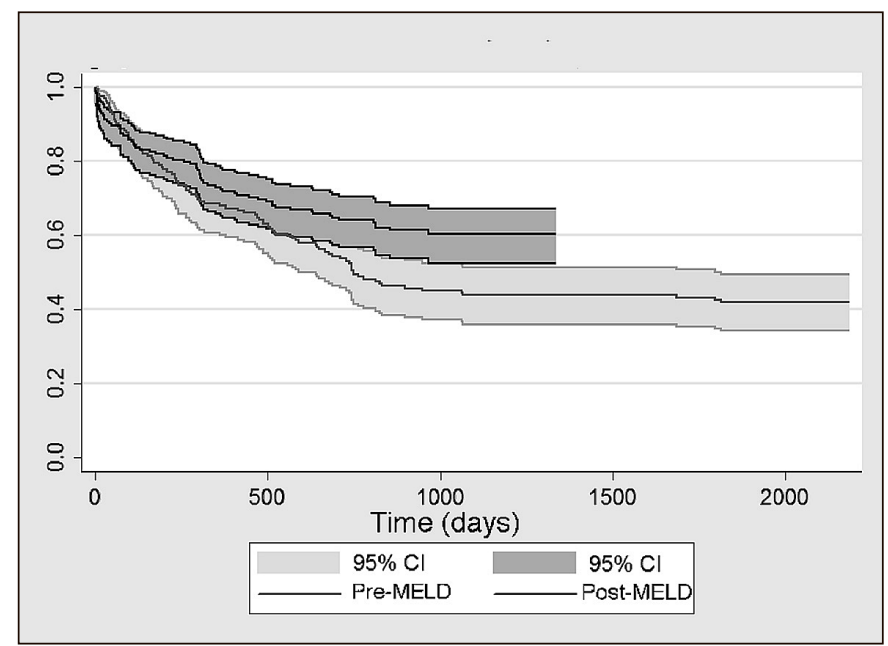

FIGURE 1. Kaplan-Meier's survival curves. Kaplan-Meier's curves for survival of enlisted patients in the pre- and post-MELD eras

Results were submitted to the Cox's regression model in order to identify the independent variables related to survival of enlisted patients. First, the variable pre- or post-MELD era was analyzed individually, being found to be significantly related to survival, with a $P=0.010$; the hazard ratio of being enlisted in the post-MELD era in relation to being enlisted in the pre-MELD period was of 0.664 (95\% CI=0.487-0.906). After that, MELD at the time of enlistment was included into the model and proved to be significantly related to survival, with a $P<0.001$ and a hazard ratio of $1.069(95 \%$ $\mathrm{CI}=1.043-1.095)$. Finally, the inclusion into the model of the variables presence of $\mathrm{HCC}(P=0.060)$, bilirubin at the time of enlistment $(P=0.320)$ and creatinine at the time of enlistment $(P=0.830)$ did not confirm to be useful, once those variables did not prove to be significantly associated to the outcome.

Kaplan-Meier's curves represent the survival function of the studied population in the period of time actually observed. In order to make possible estimating the survival of patients in longer periods of time and analyzing if the advantage of one model of allocation over the other would prevail, mathematical models were used, generating survival functions and, therefore, survival curves able to estimate the survival of a group of people beyond the observed period. For the pre-MELD group, all four parametric models were analyzed, and Gompertz's model was found to be the best fitted to the Kaplan-Meier's survival curve of the studied population (Figure 2). The survival function generated by the Gompertz's model produced a curve, which could estimate the survival for enlisted patients in the pre-MELD group regardless of being transplanted to be of $43.17 \%$ in 5 years and of $41.75 \%$ in 10 years, when the curve stabilized.

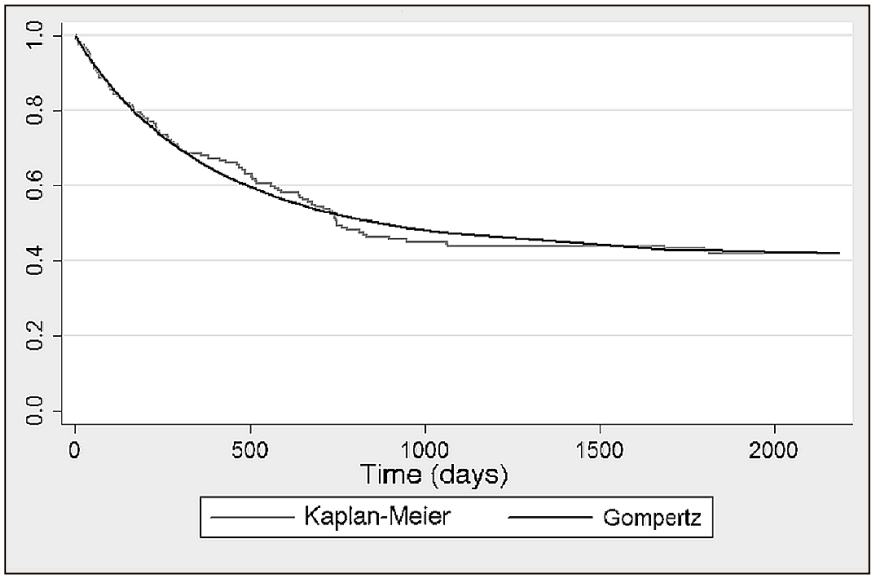

FIGURE 2. Estimates of long-term survival for the pre-MELD population. Comparison between the Kaplan-Meier's survival curve for the pre-MELD population and the curve generated by the Gompertz's model.

The analysis was also performed for the post-MELD population. The normal-log model was evaluated as the best fitted to the Kaplan-Meier's curve of the studied population (Figure 3). The normal-log model generated a curve, which could estimate the survival for enlisted patients in the postMELD group independently of being transplanted to be of $53.54 \%$ in 5 years and of $44.64 \%$ in 10 years.

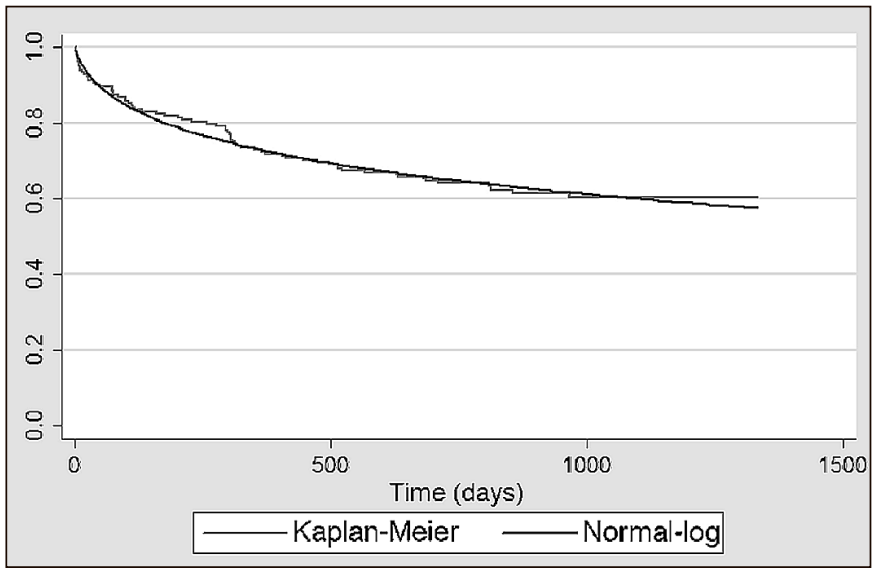

FIGURE 3. Estimates of long-term survival for the post-MELD population. Comparison between the Kaplan-Meier's survival curve for the post-MELD population and the curve generated by the normal-log model. 


\section{DISCUSSION}

The present study is the first, in Brazil, to analyze the survival in pre- and post-MELD eras from the perspective of the enlisted population, regardless of the fact of being transplanted, in an "intention-to-treat-like" manner. This is of the utmost importance, since donated organs must be thought as a scarce and public resource, which should be used in a way to provide the community with the greatest amount of life-years saved possible. This is why it is essential to evaluate survival of the pool of patients in need of the organ and not only of those who received it. Besides, this study tries to address the issue of short-term follow-ups, by creating parametric curves capable of accurately estimating the survival of the groups in any given period of time.

When analyzing both enlisted and transplanted patients, we realized that there were a decrease in the percentage of patients with an alcoholic component to their cirrhosis from the pre- to the post-MELD era and an increase in the proportion of $\mathrm{HCC}$ cases. Concerning the alcoholic etiology of liver disease, it is worth noticing that some authors have raised the question of cirrhotic patients due to alcoholism having a better outcome without transplantation than cirrhotics due to viral hepatitis ${ }^{(2)}$, and others have found that alcoholic patients had more post-transplant complications ${ }^{(30)}$. Both these remarks could reinforce that the reported trend in listing and transplanting less alcoholic patients might be positive to the system as a whole. However, when considering the increase in listing and transplanting cases of $\mathrm{HCC}$, which has already been shown by some studies ${ }^{(14,15,37)}$, there could be a concern that survival would be impaired. In fact, some authors have demonstrated that $\mathrm{HCC}$ was an independent risk factor for post-transplant mortality in a long term analysis ${ }^{(38)}$, and others have shown that the liver cancer transplanted patients had twice the risk of death than their pairs ${ }^{(5)}$. Whereas the present study could not correlate the diagnosis of $\mathrm{HCC}$ with worse survival after the logistic regression, it is important to remind that the analysis was for all enlisted patients, transplanted or not, differently from the just referred study. Besides, it is important to state that there could have been a sub-notification of HCC cases in the pre-MELD era, when, differently from now, this diagnosis would not help the candidate to receive a liver earlier.

When evaluating results for the time of enlistment (Table 1), we noticed a lower mean value of sodium in the postMELD group, as well as a higher mean value of bilirubin, which could denote a greater severity of patients already at the moment of enlistment. Mean MELD score at the time of enlistment, though, did not significantly differ between eras, making it possible to think that the severity of enlisted patients was the same in both periods, differently from what was presented in an American study ${ }^{(14)}$. However, when analyzing only patients without HCC, those for whom MELD probably reflects better the severity of the illness, we could show that MELD at the time of enlistment had increased from the pre- to the post-MELD era, and this reinforces our findings of the superiority of the MELD policy, once it prevailed even dealing with possibly sicker patients.

A lower mean value of albumin and greater mean values of total bilirubin and MELD score at the time of transplantation in post-MELD group (Table 2) reflect the greater severity of patients transplanted nowadays, a characteristic of an allocation system based on urgency.

The results of the Kaplan-Meier's curves for survival of the groups of all enlisted patients allowed the conclusion that mortality was greater in the pre-MELD group. Moreover, the parametric curves confirmed this finding even in the longterm (at least for 10 years).

Even though most studies concerning the impact of MELD-based allocation on outcomes have revealed effectiveness of the system in reducing wait-list mortality, probably without importantly affecting post-transplant survival and enhancing resource utilization ${ }^{(26)}$, the results of the present study are remarkable, because they are the first to prove, in an "intention-to-treat-like" manner, with an instrument that permits long-term analysis, in a population of consecutive patients enlisted by four different transplantation teams, that the MELD-based allocation policy brought a significant survival gain for the cirrhotic population in need of transplantation as a whole and, therefore, for all the society. This confirms that the transplantation policy has advanced, and that the benefit in life-years saved by the same policy has improved, as well as answers the question proposed by Gotthardt et al. ${ }^{(19)}$ about the superiority of MELD-based allocation strategy over the chronological system.

One might argue that survival of the post-MELD group could have been better than that of the pre-MELD group because of the evolution of medical care from a previous period of time to a posterior one. Even though this might be a bias of this study, we do not believe it was so, because periods chosen to be compared were close in time, there were not great technical advances in that time, and most of the transplant teams in activity in our State already had long experience in liver transplantation.

In the logistic regression analysis, the variables independently related to survival of the enlisted population were the era in which patients had been enlisted and their MELD score at the moment of enlistment. Patel et al. ${ }^{(29)}$ had already found pre-MELD era to be an independent risk factor for mortality, but their study referred only to transplanted patients with renal insufficiency.

There are many authors who have indicated MELD score at registration as a risk factor for mortality in wait-list ${ }^{(4,18,22)}$ or MELD score before transplantation as a risk-factor for death after the procedure ${ }^{(5,14,18,20,23,27,34)}$. Nevertheless, this is the first time MELD score at the time of registration is reported to be an independent risk factor for mortality regardless of transplantation. This fact did not make survival in the post-MELD era worse than that of the pre-MELD period, even knowing that, excluded the cases of HCC, mean MELD value at registration was higher in the post-MELD group.

Finally, it is essential to keep pursuing better manners to revert the organ shortage into the greatest life-years gain 
possible for the cirrhotic population. MELD-based system is probably not the ultimate step in this pursuit, and benefitbased allocation models should still be investigated further. The present study, though, could conclude that MELD-based transplantation policy is superior to the chronology-based one, presenting a much better survival for the entire popu- lation in need of an organ, regardless of the fact of being transplanted. This study could also show that long-term survival estimates for the enlisted population is better in the post-MELD era, meaning that the advantage of the current policy remains over time. Therefore, it is safe to affirm that current liver transplantation policies are in the right path.

Mattos AZ, Mattos AA, Sacco FKF, Hoppe L, Oliveira DMS. Análise da sobrevida de pacientes cirróticos listados para transplante ortotópico de fígado nas eras pré e pós MELD no Sul do Brasil. Arq Gastroenterol. 2014,51(1):46-52.

RESUMO - Contexto - O transplante é a única cura para a cirrose descompensada. O Model for End-Stage Liver Disease (MELD) é usado na alocação de órgãos. Objetivos - Comparar a sobrevida da população listada para transplante nas eras pré e pós-MELD e estimar sua sobrevida a longo prazo. Métodos - Este é um estudo retrospectivo, de cirróticos listados para transplante nas eras pré e pós-MELD. Curvas de sobrevida foram criadas através do modelo de Kaplan-Meier. O modelo de Cox foi utilizada para determinar fatores de risco para mortalidade. Os modelos exponencial, Weibull, log-normal e Gompertz foram usados para estimar sobrevida de longo prazo. Resultados - Incluíram-se 162 pacientes listados na era pré-MELD e 184 listados na pós-MELD. A curva de Kaplan-Meier para os pacientes listados na era pós-MELD foi melhor que a da pré-MELD $(P=0,009)$. Esta diferença permaneceu nas estimativas de longo prazo, com sobrevida de 53,54\% em 5 anos e de 44,64\% em 10 anos para pacientes listados na era pós-MELD e de 43,17\% e 41,75\% no período pré-MELD. A era em que os pacientes eram listados $(P=0,010)$ e o MELD de inscrição $(P<0,001)$ estiveram associados de maneira independente à sobrevida, com razão de riscos de 0,664 (intervalo de confiança-IC 95\% $=0,487-0,906$ ) e de 1,069 (IC $95 \%=1,043-1,095)$. Conclusão - A política de transplantes baseada no escore MELD é superior à baseada no tempo de espera em lista, promovendo melhor sobrevida, mesmo em longo prazo.

DESCRITORES - Cirrose hepática. Transplante de fígado. Análise de sobrevida. 


\section{REFERENCES}

1. Amin MG, Wolf MP, TenBrook JA, Freeman RB, Cheng SJ, Pratt DS, Wong JB Expanded criteria donor grafts for deceased donor liver transplantation under the MELD system: a decision analysis. Liver Transpl. 2004;10:1468-75.

2. Angermayr B, Luca A, König F, Bertolini G, Ploner M, Gridelli B, Ulbrich G, Reiberger T, Bosch J, Peck-Radosavljevic M. Aetiology of cirrhosis of the liver has an impact on survival predicted by the Model of End-stage Liver Disease score. Eur J Clin Invest. 2009;39:65-71.

3. Arvaniti V, D’Amico G, Fede G, Manousou P, Tsochatzis E, Pleguezuelo M, Burroughs AK. Infections in patients with cirrhosis increase mortality four-fold and should be used in determining prognosis. Gastroenterology. 2010;139:1246-56.

4. Brandão A, Fuchs SC, Gleisner AL, Marroni C, Zanotelli ML, Cantisani G. Model for the end-stage liver disease and death prediction in a cohort of Brazilian patients on the waiting list for liver transplantation. Clin Transplant. 2008;22:651-6.

5. Brandão A, Fuchs SC, Gleisner AL, Marroni C, Zanotelli ML, Cantisani G, Liver Transplantation Group. MELD and other predictors of survival after liver transplantation. Clin Transplant. 2009;23:220-7.

6. Brasil. Ministério da Saúde. Secretaria de Assistência à Saúde. Portaria GM n 1160 de 29 de maio de 2006. Diário Oficial da União nº 103, Brasília, 31 de maio de 2006.

7. Brown RS, Kumar KS, Russo MW, Kinkhabwala M, Rudow DL, Harren P, Lobritto S, Emond JC. Model for end-stage liver disease and Child-Turcotte-Pugh score as predictors of pretransplantation disease severity, posttransplantation outcome, and resource utilization in United Network for Organ Sharing status 2A patients. Liver Transpl. 2002;8:278-84.

8. D'Amico G, Garcia-Tsao G, Pagliaro L. Natural history and prognostic indicators of survival in cirrhosis: a systematic review of 118 studies. J Hepatol. 2006;44: 217-31.

9. D'Amico G. Stages Classification of Cirrhosis: Where Do We Stand? In: de Franchis R, ed. Portal Hypertension V: Proceedings of the Fifth Baveno International Consensus Workshop. 5th ed. Oxford: Wiley-Blackwell. 2011:132-9.

10. de Franchis R. Evolving consensus in portal hypertension. Report of the Baveno IV consensus workshop on methodology of diagnosis and therapy in portal hypertension. J Hepatol. 2005;43:167-76.

11. de Franchis R, Faculty BV. Revising consensus in portal hypertension: report of the Baveno $\mathrm{V}$ consensus workshop on methodology of diagnosis and therapy in portal hypertension. J Hepatol. 2010;53:762-8.

12. Durand F, Valla D. Assessment of the prognosis of cirrhosis: Child-Pugh versus MELD. J Hepatol. 2005;42(suppl 1):100-7.

13. Foxton MR, Al-Freah MA, Portal AJ, Sizer E, Bernal W, Auzinger G, Rela M, Wendon JA, Heaton ND, O'Grady JG, Heneghan MA. Increased model for end-stage liver disease score at the time of liver transplant results in prolonged hospitalization and overall intensive care unit costs. Liver Transpl. 2010;16:668-77.

14. Freeman RB, Wiesner RH, Edwards E, Harper A, Merion R, Wolfe R, United Network for Organ Sharing Organ Procurement and Transplantation Network Liver and Transplantation Committee. Results of the first year of the new liver allocation plan. Liver Transpl. 2004;10:7-15

15. Freitas AC, Itikawa WM, Kurogi AS, Stadnik LG, Parolin MB, Coelho JC. The impact of the model for end-stage liver disease (MELD) on liver transplantation in one center in Brazil. Arq Gastr. 2010;47:233-7.

16. Garcia-Tsao G. Hepatic Venous Pressure Gradient, Biopsy or Both? In: de Franchis R, ed. Portal Hypertension V: Proceedings of the Fifth Baveno International Consensus Workshop. 5th ed. Oxford: Wiley-Blackwell; 2011:9-17.

17. Gheorghe L, Iacob S, Iacob R, Gheorghe C, Popescu I. Variation of the MELD score as a predictor of death on the waiting list for liver transplantation. J Gastrointestin Liver Dis. 2007;16:267-72.

18. Gleisner AL, Muñoz A, Brandão A, Marroni C, Zanotelli ML, Cantisani GG, Moreira LB, Choti MA, Pawlik TM. Survival benefit of liver transplantation and the effect of underlying liver disease. Surgery. 2010;147:392-404.

19. Gotthardt D, Weiss KH, Baumgärtner M, Zahn A, Stremmel W, Schmidt J, Bruckner T, Sauer P. Limitations of the MELD score in predicting mortality or need for removal from waiting list in patients awaiting liver transplantation. BMC Gastroenterol. 2009;9:72

20. Habib S, Berk B, Chang CC, Demetris AJ, Fontes P, Dvorchik I, Eghtesad B, Marcos A, Shakil AO. MELD and prediction of post-liver transplantation survival. Liver Transpl. 2006;12:440-7.
21. Huo TI, Lin HC, Wu JC, Lee FY, Hou MC, Lee PC, Chang FY, Lee SD. Proposal of a modified Child-Turcotte-Pugh scoring system and comparison with the mode for end-stage liver disease for outcome prediction in patients with cirrhosis. Liver Transpl. 2006;12:65-71

22. Kamath PS, Wiesner RH, Malinchoc M, Kremers W, Therneau TM, Kosberg CL, D'Amico G, Dickson ER, Kim WR. A model to predict survival in patients with end-stage liver disease. Hepatology. 2001;33:464-70.

23. Lee YM, Fernandez M, Da Costa M, Lee KH, Sutedja DS, Tai BC, Tan KC, Isaac J, Prabhakaran K, Lim SG. MELD may not be the better system for organ allocation in liver transplantation patients in Singapore. Singapore Med J. 2006;47:592-4

24. Malinchoc M, Kamath PS, Gordon FD, Peine CJ, Rank J, ter Borg PC. A model to predict poor survival in patients undergoing transjugular intrahepatic portosystemic shunts. Hepatology. 2000;31:864-71.

25. Murray CJ, Lopez AD. Alternative projections of mortality and disability by cause 1990-2020: Global Burden of Disease Study. Lancet 1997;349:1498-504.

26. Neuberger J. The introduction of MELD-based organ allocation impacts 3-month survival after liver transplantation by influencing pretransplant patient characteristics. Transpl Int. 2009;22:979-81.

27. Onaca NN, Levy MF, Sanchez EQ, Chinnakotla S, Fasola CG, Thomas MJ, Weinstein JS, Murray NG, Goldstein RM, Klintmalm GB. A correlation between the pretransplantation MELD score and mortality in the first two years after liver transplantation. Liver Transpl. 2003;9:117-23.

28. Palmiero HO, Kajikawa P, Boin IF, Coria S, Pereira LA. Liver recipient survival rate before and after model for end-stage liver disease implementation and use of donor risk index. Transplant Proc. 2010;42:4113-5.

29. Patel HK, Patel A, Abouljoud M, Divine G, Moonka DK. Survival after liver transplantation in patients who develop renal insufficiency. Transplant Proc. 2010;42:4167-70.

30. Patkowski W, Zieniewicz K, Skalski M, Krawczyk M. Correlation between selected prognostic factors and postoperative course in liver transplant recipients Transplant Proc. 2009;41:3091-102.

31. Pestana RC, Baracat EI, Massarollo PCB, Pereira LA, Szutan LA. Consequences of the implementation of the Model for End-stage Liver Disease system for liver allocation in Brazil. Transplant Proc. 2013;45:2111-4.

32. Pugh RN, Murray-Lyon IM, Dawson JL, Pietroni MC, Williams R. Transection of the oesophagus for bleeding oesophageal varices. Br J Surg. 1973;60:646-9.

33. Ravaioli M, Grazi GL, Dazzi A, Bertuzzo V, Ercolani G, Cescon M, Cucchetti A, Masetti M, Ramacciato G, Pinna AD. Survival benefit after liver transplantation a single European center experience. Transplantation. 2009;88:826-34.

34. Saab S, Wang V, Ibrahim AB, Durazo F, Han S, Farmer DG, Yersiz H, Morrisey M, Goldstein LI, Ghobrial RM, Busuttil RW. MELD score predicts 1-year patient survival post-orthotopic liver transplantation. Liver Transpl. 2003;9:473-6.

35. Schaubel DE, Guidinger MK, Biggins SW, Kalbfleisch JD, Pomfret EA, Sharma P, Merion RM. Survival benefit-based deceased-donor liver allocation. Am J Transplant. 2009;9:970-81.

36. Sharma P, Schaubel DE, Guidinger MK, Merion RM. Effect of pretransplant serum creatinine on the survival benefit of liver transplantation. Liver Transp 2009; $15: 1808-13$

37. Thuluvath PJ, Guidinger MK, Fung JJ, Johnson LB, Rayhill SC, Pelletier SJ. Liver transplantation in the United States, 1999-2008. Am J Transplant. 2010;10:1003-19.

38. Vrochides D, Hassanain M, Barkun J, Tchervenkov J, Paraskevas S, Chaudhury P, Cantarovich M, Deschenes M, Wong P, Ghali P, Chan G, Metrakos P. Association of preoperative parameters with postoperative mortality and long-term survival after liver transplantation. Can J Surg. 2011;54:101-6.

39. Weismüller TJ, Fikatas P, Schmidt J, Barreiros AP, Otto G, Beckebaum S, Pau A, Scherer MN, Schmidt HH, Schlitt HJ, Neuhaus P, Klempnauer J, Pratschke J, Manns MP, Strassburg CP. Multicentric evaluation of model for end-stage liver disease-based allocation and survival after liver transplantation in Germany limitations of the 'sickest first'-concept. Transpl Int. 2011;24:91-9.

40. Wiesner R, Edwards E, Freeman R, Harper A, Kim R, Kamath P, Kremers W, Lake J, Howard T, Merion RM, Wolfe RA, Krom R, United Network for Organ Sharing Liver Disease Severity Score Committee. Model for end-stage liver disease (MELD) and allocation of donor livers. Gastroenterology. 2003;124:91-6. 